Przegląd Badań Edukacyjnych Educational Studies Review

ISSN 1895-4308

nr 19 (2/2014), s. 167-180

METAANALIZY

BADAŃ

EDUKACYJNYCH

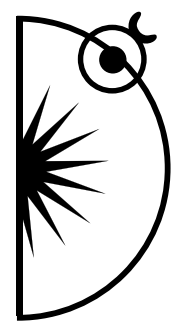

Iwona Murawska

Uniwersytet Mikołaja Kopernika w Toruniu, e-mail: murawska@doktorant.umk.pl

\title{
Współczesne tendencje w polskich badaniach nad zdolnościami
}

DOI: http://dx.doi.org/10.12775/PBE.2014.027

\section{Contemporary Trends in Polish Research on Skills}

\begin{abstract}
The article is an attempt to systematise modern research on skills, as well as to show the recent trends in the subject. The author combines the analysed studies into categories and looks for contexts and practical premises regarding the issue in question. She indicates the importance of skills in building the society of innovative competences.
\end{abstract}

Keywords: abilities, gifted student, research, modernity, competence.

\section{Wprowadzenie}

Zdolności wciąż stanowią dla naukowców otwarty i interesujący poznawczo obszar badawczy. Przemiany życia społecznego, a zatem i ludzi, wymuszają nieustanne aktualizacje i rozwinięcia w obrębie zakresów danych, a także formułowanie nowych problemów badawczych w odpowiedzi na potrzeby poznawania ludzkich zdolności. W XXI stuleciu, określanym jako wiek informacji i kompetencji, badania nad ludzkimi możliwościami i ich atrybucją mogą stać się obszarem, który wyznacza kierunek działań wielu dziedzin. Może w związku z tym dziwić stosunkowo niewielkie zainteresowanie tematyką zdolności, które wciąż jawią się jako niszowe w kręgach naukowych zainteresowań badawczych i funkcjonujące przed szeregiem praktyki edukacyjno-społecznej. 
Celem niniejszego artykułu jest wskazanie najnowszych tendencji w badaniach nad zdolnościami oraz pewnych kategorii w ich obrębie. Nie bez znaczenia pozostaje tu uwzględnienie szerokiego kontekstu, problemów i praktycznych przesłanek w zakresie analizowanej problematyki. Autorka wyszła z założenia, że badania nad zdolnościami nie tylko ewoluowały, ale także dokonały pewnego przeorganizowania i rozdrobnienia. Niestety same badania wraz z badaczami, funkcjonują najczęściej w ramach samotnych wysp i trudno tu mówić o tworzeniu się spójnego i silnego paradygmatu, który mógłby być mocną podstawą do traktowania zdolności jako kluczowego kapitału, zarówno indywidualnego, jak i społecznego.

W tekście dokonano podziału na kategorie badań, związanych ze środowiskiem ucznia zdolnego, szkoła jako inhibitorem lub stymulatorem zdolności, nauczycielem, twórczością, psychologią i psychiatrią, rodzina, niepowodzeniami uczniów zdolnych, a także związanych nierozerwalnie z praktyką edukacyjną, które wydały mi się wiodącymi w ostatnich latach. Niniejsze opracowanie może przyczynić się do kompleksowej dyskusji i szerszego postrzegania tematu, przy rosnących potrzebach wynikających z przemian społeczno-kulturowych i potrzeb XXI wieku.

\section{Wcześniejsze badania nad zdolnościami}

Pionierskie badania zdolności Francisa Galtona przyczyniły się do lepszego zrozumienia zdolności człowieka, a Alfredowi Binetowi zawdzięczamy rozpoczęcie kompleksowych badań nad inteligencją i narzędziami do jej mierzenia (Limont, 2012, s. 42). Jednak bezpośrednim inspiratorem współczesnego nurtu w badaniach nad zdolnościami, także dla polskich badaczy, jest niewątpliwie Joseph Renzulli, według którego zdolności mają złożony charakter i nie można ich określać na podstawie jednego wskaźnika, np. inteligencji. W jego trójpierścieniowym modelu zdolności, który pozwala na rozwinięcie się wybitnych umiejętności, znalazły się zdolności twórcze, ponadprzeciętne zdolności oraz zaangażowanie w zadanie (Limont, 2012, s. 54-59). Z kolei Franz Mönks, w swoim wieloczynnikowym modelu zdolności rozszerzył tę teorię o czynniki zewnętrzne, do których zaliczył szkołę, rówieśników i rodzinę (Limont, 2012, s. 66-68). Krokiem milowym w dyskusji na temat zdolności stała się także koncepcja inteligencji wielorakich Howarda Gardnera, który proponuje osiem inteligencji, a wśród nich: językową, logiczno-matematyczną, muzyczną, cielesno-kinetyczna, przestrzenna, interpersonalną, intrapersonalną i przyrodniczą (Limont, 2012, s. 46-48). 
Na gruncie polskim znaczące okazały się badania Ludwika Bandury, który analizując kilkadziesiąt przypadków wskazanych przez nauczycieli jako szczególnie rokujących pośród innych uczniów i różnych klas, także przyczynił się do rozwoju badań nad zdolnościami. Można wręcz zaznaczyć, że panujący wtedy system polityczny naprowadził go na tor inteligencji wielorakiej, w świetle której każdy może mieć predyspozycje i rozwijać je, gdyż ludzie o różnych zdolnościach są potrzebni dla budowania wspólnego, społecznego dobra (Bandura, 1974). Potrzebę podnoszenia poziomu nauczania w szkole, a także podwyższania kwalifikacji społeczeństwa i niwelowania niepowodzeń dostrzega Czesław Kupisiewicz, widząc narastającą konieczność pozyskiwania ludzi o wysokich i wielorakich umiejętnościach (Borzym, 1979, s. 5-8). Kolejne zwrócenie uwagi na problemy uczniów o wysokich możliwościach postulowała także kilkadziesiąt lat temu Irena Borzym, podejmując szeroko rozumiane poznanie uczniów zdolnych i dyskurs nad ich właściwym funkcjonowaniem w szkole, a także poza nią. Podkreśla ona, że to właśnie z uczniami zdolnymi społeczeństwo wiąże największe nadzieje (Borzym, 1979).

\section{Tendencje}

W aktualnych badaniach nad zdolnościami można zauważyć kilka dominujących tendencji. Jedną z nich jest szczególne znaczenie kontekstu i przemian społecznych, które w znaczny sposób rzutują na owe badania. Człowiek, a także uczeń zdolny, są kompatybilną częścią świata społecznego, zatem jako umiejscowieni w konkretnym miejscu i czasie, także podlegają jego wpływom. Kolejno, w rezultacie popularyzacji wiedzy z zakresu koncepcji i modeli zdolności, coraz częściej bardziej aniżeli intelektualne predyspozycje, w pierwszej kolejności uwzględnia się czynniki zewnętrzne - środowisko i jego oddziaływania, czy psychologiczne. Duże znacznie może mieć w tej kwestii rozpowszechnienie w środowisku badaczy Wieloczynnikowego Modelu Zdolności Franza Mönksa.

Szkoła nie jest już tylko miejscem pobierania edukacji, czyli kształcenia i wychowania, ale również stymulatorem lub inhibitorem zdolności. Badania z zakresu zdolności są prowadzone interdyscyplinarnie, z wykorzystaniem dorobku wielu dziedzin, co pozwala na szerokie zastosowanie wyników i zwiększa świadomość z zakresu prowadzenia kompleksowych badań, z uwzględnieniem różnorodnej, uzupełniającej się wiedzy. Zdolności są jednak często traktowane także fragmentarycznie jako temat szeroki, mglisty niejednoznaczny, potencjalnie łatwy, podatny na wycinkowość i stereotypizację. Badacze niekiedy zajmu- 
ją się nim okazjonalnie, bez gruntownego przygotowania - z racji konferencji, zbliżającej się publikacji czy też naukowej mody. Uczeń zdolny w badaniach wciąż jest traktowany jako osoba osiągająca wymierne efekty, wskazana przez nauczyciela bądź pozytywnie przechodząca przez testy psychologiczne. Brakuje w tym zakresie spojrzenia bardziej egalitarnego, obejmującego także zdolności miękkie, trudne do zmierzenia, co umożliwiłoby wykorzystanie szerokich potencjałów pojęcia określającego ucznia zdolnego.

\section{Szkoła}

W edukacyjnym procesie odkrywania i rozwijania talentów istotną rolę odgrywają placówki oświatowe. Ich zadaniem jest zapewnianie najlepszych możliwości rozwoju i przygotowanie podopiecznych do optymalnego funkcjonowania w zastanym świecie, szkoła stanowi bowiem swoistą miniaturę społeczeństwa, także w zakresie kreowania świata społecznego. W licznych badaniach szkoła jest przedstawiana jako stymulator bądź inhibitor zdolności. W opinii Małgorzaty Stańczak wiele (wyselekcjonowanych) placówek w województwie warmińsko-mazurskim w zadowalającym stopniu spełnia swe zadania w zakresie wspierania rozwoju uczniów zdolnych. Badaniami objęta została oferta edukacyjna dla uczniów zdolnych w postaci zajęć lekcyjnych i pozalekcyjnych wybranych szkół, a także jej efektywność w zakresie zaspokajania wybranych potrzeb uczniów zdolnych (Stańczak, 2009, s. 179-188). Badania wykazały zarówno potencjały, jak i braki danych szkół w zakresie zaspokajania potrzeb uczniów zdolnych. Większość z nich była realizowana w ramach zajęć pozalekcyjnych, jednak nie wszystkie spełniały specyficzne oczekiwania tej grupy. Z kolei rozbudowane studium Teresy Gizy, z zakresu pedagogicznych i społecznych działań wspierających rozwój uczniowskich zdolności, stało się przyczynkiem do zbadania społecznych kontekstów funkcji realizowanych przez szkołę, a także ich znaczeń. Autorka w szerokim zakresie, zarówno teoretycznie, jak i empirycznie, przybliża czytelnikowi tematykę zdolności rozwijanych z udziałem otoczenia, które nigdy nie jest dla nich neutralne (Giza, 2006, s. 13-15).

Szkoła w badaniach nad zdolnościami jest często przedmiotem konstruktywnej krytyki. Zbyszko Melosik kategorycznie twierdzi, że edukacja polska na poziomie podstawowym i średnim jest kuźnią zgubionych talentów. Krzysztof Szmidt zarzuca szkole przedmiotowe traktowanie ucznia i małą dbałość o jego osobowość, a także ograniczenia w zakresie rozwoju zdolności twórczych, a Wiesława Limont podkreśla, że w polskiej szkole równa się do przeciętności i dąży się do wykształcenia u uczniów określonych zachowań, biorąc pod uwa- 
gę chociażby szybkość i poprawność odtwarzanego materiału (Dyrda, 2012, s. 161-162).

\section{Nauczyciel}

W rozważaniach nad rolą szkoły w kształceniu potencjałów uczniów, nie sposób ominąć zamysłu pedeutologicznego. Nauczyciel jako wykwalifikowany specjalista nie pozostaje obojętny w kwestii wpływu na rozwój zdolności swoich uczniów. Zaznaczając wieloaspektowość zawodu nauczyciela, różnorodność sytuacji wychowawczych i środowisk działania, jego praca jest wciąż aktualnym obszarem badawczym w zakresie wspierania dzieci o specjalnych potrzebach edukacyjnych.

Joanna Cieślikowska w swych badaniach zajmuje się miejscem i rolą nauczyciela $\mathrm{w}$ procesie rozwoju zdolności. $\mathrm{W}$ jednej $\mathrm{z}$ analiz przywołuje znaczenie nauczyciela ucznia zdolnego w perspektywie J. Renzulliego. W przedstawionym przez niego trójpierścieniowym modelu zdolności, szczególną rolę odgrywa nauczyciel, który zdaniem badacza powinien mieć te same właściwości, co sam uczeń zdolny (Cieślikowska, 2008, s. 27-37), w kolejnych, wraz z W. Limont, zastanawia się nad obrazem ucznia zdolnego w potocznych ocenach nauczycieli. Badania wykazują, że prywatne doświadczenia i potoczne sądy nauczycieli, a także stereotypy mają wpływ na postrzeganie przez nich ucznia zdolnego (Cieślikowska, Limont, 2010, s. 11-26). Dominika Bardzińska podkreśla znaczenie specjalnych kompetencji nauczyciela ucznia zdolnego i dużych wymagań w zakresie jego umiejętności. Zwraca też uwagę na niewystarczający aspekt możliwości ich rozwoju w polskiej praktyce edukacyjnej, która często mija się z idealistyczną teorią (Bardzińska, 2013, s. 94-102). Wyjątkowo znaczenie pedagoga dla rozwoju specjalnych zdolności podopiecznych widzi Katarzyna Gabryś, która w zawodzie nauczyciela upatruje rodzaj specjalnej odpowiedzialności - odpowiedzialność moralną, współodpowiedzialność nauczycieli i rodziców za jego optymalny rozwój, w szczególności w aspekcie specjalnych potrzeb edukacyjnych (Gabryś, 2008, s. 24-36).

\section{Twórczość}

Pojęcie specjalnych zdolności często i zasadnie jest utożsamiane z aktem twórczym. Wymiarów twórczości badacze doszukują się w edukacji, sztukach plastycznych czy muzyce. Specyficzne zdolności mogą wykształcić się bowiem także w relacji ze sztuką. Rozważania nad potrzebą stymulowania twórczych 
zachowań uczniów czyni Franz Mönks, podkreślając jednak, że pomimo dostrzegania przez nauczycieli potrzeby stymulowania twórczych zachowań uczniów, nauczyciele paradoksalnie kreatywnych uczniów nie lubią (Mönks, 2005, s. 19-30). W badaniach pojawia się też aspekt rozwijania twórczych kompetencji nauczycieli dla oddziaływania na takowe postawy wśród uczniów (Dyrda, Przybylska, 2008, s. 101-110). Twórcze działania podmiotu w dobie globalizacji i predyspozycje do owego kreatywnego bycia we wciąż zmieniającym się świecie bez granic, zostały dostrzeżone przez Marcina Jaworskiego, który w płynny sposób połączył akt twórczy z aspektem aktualizacji, modernizacji i zmiany (Jaworski, 2010, s. 75-88). Janina Uszyńska-Jarmoc twórczość rozumie nie jako cel, a działanie o wymiarze kreacyjnym i autokreacyjnym, które pomaga w konstruowaniu wiedzy o sobie i świecie. Własna biografia dziecka jest tu traktowana jako płaszczyzna i inspiracja do podejmowania aktywności twórczej (Uszyńska-Jarmoc, 2008, s. 199-208). Opracowana Przez W. Limont metoda synektyczna nadal jest inspiracją dla teoretyków i praktyków oświaty. Anna Przybylska powołuje się na metodę jako stymulator rozwoju wyobraźni oraz ujawniania twórczych zdolności dzieci w wieku 5-15 lat (Przybylska, 2005, s. 153-164). Specjalnymi zasadami kierują się również zdolności z zakresu przedmiotów artystycznych, gdzie sam fakt posiadania talentu niewiele znaczy bez ciężkiej pracy, samorealizacji, pomocy ze strony nauczyciela. Julia Kaleńska przedstawia złożony obraz wymagań wobec ucznia zdolnego w opinii nauczycieli szkół muzycznych, realizujący się głównie w obrębie kompetencji specjalistycznych. Zwraca również uwagę na znaczenie nauczyciela dla indywidualnego rozwoju talentu podopiecznego (Kaleńska, 2008, s. 13-28). Bernadeta Didkowska w swoich pracach podejmuje zagadnienia twórczości plastycznej i kultury wizualnej z uwzględnieniem rozwoju uzdolnień, w tym przypadku poddaje analizie rysunek komiksowy jako jeden $\mathrm{z}$ wielu elementów kulturotwórczych (Didkowska, 2008, s. 75-88). Nadmienić należy także, że badania dotyczące twórczości prowadzi nieustannie autorytet $\mathrm{w}$ zakresie pedagogiki twórczości - Krzysztof Szmidt, którego teksty i wyniki są inspiracją dla wielu badaczy tego zakresu zdolności (Szmidt, 1997, 2001, 2007, 2010). W Uniwersytecie Mikołaja Kopernika w Toruniu, 6 maja 2014 r. odbyła się obrona pracy doktorskiej mgr Dominiki Jastrzębskiej pt. Rozwój zdolności i wyobraźni twórczej uczniów w wieku 7-18 lat, wypromowana pod kierunkiem prof. W. Limont. Rozprawa zawiera kompleksowe i rozbudowane wyniki badań na temat potencjału twórczego uczniów na różnych szczeblach edukacji, w różnych szkołach, ze szczególnym uwzględnieniem wieku rozwojowego wychowanków (https:// apd.umk.pl/pl/diplomas/phd/88962/). 


\section{Niepowodzenia}

Uczeń zdolny nie jest postrzegany wyłącznie jako osoba osiagająca sukcesy. Aspekt niepowodzeń szkolnych uczniów zdolnych, choć rzadko dostrzegany w praktyce, gdzie uczeń napotykający trudności przestaje być uczniem zdolnym, został w ostatnich latach dobrze opracowany teoretycznie. Kompleksowo i praktycznie do problemu niepowodzeń szkolnych uczniów zdolnych podchodzi Beata Dyrda. Jej zdaniem co dziesiąty uczeń w szkole uczy się znaczenie poniżej swoich możliwości. W wielu czynnikach dopatruje się przyczyn niepowodzeń, szuka praktycznych rozwiązań podbudowanych teorią, w celu przeciwdziałania owym niepowodzeniom. Wyjaśnia także pojęcie syndromu nieadekwatnych osiągnięć szkolnych, który rozumie jako niekorzystną sytuację, w jakiej uczniowie zdolni nie wykorzystują swoich możliwości i wskazuje elementy, które mogą ułatwić jego rozpoznanie. Za Nicholasem Colangelo zaznacza również, że tendencje do pojawiania się syndromu mogą ujawnić się już w pierwszych latach nauki szkolnej i podkreśla periodyczną bądź epizodyczną możliwość ujawnienia się go w dowolnym momencie (Dyrda, 2007, s. 7-10, 43).

\section{Psychologia i psychiatria}

W ostatnim czasie zaczyna rozwijać się nurt badań z pogranicza psychologii i psychiatrii nad zdolnościami. Zaliczyć do nich możemy wykorzystanie zapomnianej dziś koncepcji dezintegracji pozytywnej Kazimierza Dąbrowskiego jako inspiracji do interdyscyplinarnych badań nad zdolnościami. Koncepcja ta podkreśla, że aby osobowość osiagnęła wyższe, świadome stadium, musi przejść przez pewien proces dezintegracji, który ma tu konotacje pozytywne i pozwala na przyspieszony i twórczy krok w kierunku dochodzenia do ideału osobowości. Wskazuje się również na charakteryzującą osoby zdolne pobudliwość psychiczną w zakresie poznawczym. Koncepcję tę wykorzystują w swoich badaniach M. M. Piechowski i W. Limont (Limont, 2012, s. 62-66).

Zdolności jako asynchronię rozwojową dostrzega W. Limont, która zaznacza, że osób zdolnych dotyczą również liczne problemy rozwojowe, a same osoby zdolne często są postrzegane jako znacznie odbiegające od wyznaczanych standardów, o nietypowej ścieżce i drodze rozwojowej ujawniającej się w biografii danej jednostki (Limont, 2013, s. 153-160).

Badań nad zdolnościami nie sposób prowadzić bez doświadczeń współczesnej psychologii. W poszukiwaniu różnic indywidualnych w funkcjonowaniu intelektualnym człowieka szansę widzi Andrzej Sękowski, dostrzegając i pod- 
kreślając znaczenie różnych rodzajów inteligencji, także mądrości życiowej i twórczości w korelacji z wybitnymi zdolnościami (Sękowski, 2005, s. 173-189). Wiesława Limont podkreśla istnienie różnic w przetwarzaniu informacji u osób o różnych typach umysłowości. Prowadziła badania eksperymentalne, które miały odpowiedzieć na pytanie: Która z metod edukacji, ta oparta na aktywności werbalnej czy ta oparta na aktywności wizualnej, jest skuteczniejsza w pobudzaniu rozwoju zdolności i wyobraźni twórczej?

Zdolności twórcze wskazały związek z myśleniem metaforycznym, co czyni je bardziej wizualno-przestrzennymi aniżeli pojęciowymi (Limont, 2005, s. 65-79). Małgorzata Kossowska zwraca uwagę na psychologiczne uwarunkowania osiagnięć szkolnych, na które składa się inteligencja, osobowość i style uczenia się oraz zastanawia się, jak praktycznie wykorzystać wiedzę z zakresu tych uwarunkowań osiagnięć szkolnych (Kossowska, 2005, s. 47-62). Sękowski jest autorem kilku nowatorskich pozycji (z perspektywy psychologicznej) w badaniach nad zdolnościami. Wśród nich możemy znaleźć pracę dotycząca osiagnnięć uczniów zdolnych (Sękowski, 2001). Warto podkreślić, że wyróżnił on także dwie strefy w strukturze osobowości: dyspozycyjną i emocjonalno-motywacyjną (Giza, 2006, s. 43). Znacząca w kontekście omawianej problematyki jest również propozycja Macieja Karwowskiego, który nadaje zdolnościom złożoną strukturę, przy czym podkreśla znaczenie inteligencji społecznej, emocjonalnej, a także intuicji w dążeniu do sukcesu (Karwowski, 2005). Na pozaintelektualne czynniki zwraca uwagę także Chruszczewski, który wyznaczniki sprawności wykonywania różnych operacji umysłowych traktuje nader szeroko (Chruszczewski, 2013).

\section{Praktyka edukacyjna}

Badania edukacyjne są także bezpośrednio związane z praktyką edukacyjną, mają bowiem dostarczać praktycznych inspiracji do pracy z wychowankiem. Kwestie związane z edukacyjnym wspieraniem uczniów zdolnych i praktycznymi wskazówkami w tym zakresie uważam za bardzo cenne w pracy pedagogicznej. Ośrodek Rozwoju Edukacji, który zajmuje się także wspieraniem zdolności, wydał w ostatnim czasie (2013) bezpłatną publikację w ramach Europejskiego Funduszu Społecznego, dotycząca modeli pracy z uczniem zdolnym w gimnazjum, której celem jest popularyzacja wiedzy na temat uczniów zdolnych. Pozycja zawiera podstawowe pojęcia związane z tematyką zdolności, wybrane modele pracy, etapy modelu pracy z uczniem zdolnym, a także niezbędnik, który może się okazać pomocny nauczycielowi (Dąbrowska i in., 2013, s. 57). 
Swoistym kompendium w badaniach nad zdolnościami jest książka B. Dyrdy dotycząca edukacyjnego wspierania rozwoju uczniów zdolnych. Pozycja jest rozbudowaną kompilacją wiedzy na temat zdolności, współczesnych badań, rozwiązań systemowych, oddziaływania środowiska na rozwój ucznia zdolnego. Uwagę czytelnika zwracaja jednak gruntownie opisane na łamach tej pracy badania. Tytułowe edukacyjne wspieranie uczniów zdolnych zostało w pracy ujęte kompleksowo. Badaniom zostały poddane placówki i ich organizacja pracy, praca dydaktyczna, projekty i pomoc psychologiczno-pedagogiczna, czyli dotycząca całości oddziaływań pracy szkoły. Następnie wnikliwie zbadani zostali nauczyciele, opisujący wiele aspektów swojej pracy, sposób pracy i postrzegania uczniów zdolnych, a także trudności z niej wynikające. Kolejno do badań przystąpili uczniowie zdolni, którzy w narracjach przestawili swoje biografie edukacyjne, od wczesnego dzieciństwa, poprzez stan obecny, po plany i aspiracje. Praca stanowi zatem integralne ujęcie zdolności i kompleksowe zbadanie pracy szkoły w omawianym zakresie (Dyrda, 2012, s. 11-22, 453472). W tej materii nie brak także podręczników i poradników dla rodziców, pedagogów, badaczy oraz nauczycieli uczniów zdolnych. Wśród nich można wyodrębnić pozycje, które radza, jak rozwijać zdolności dziecka (Czaja-Chudyba, 2009), czy serię wydawaną przez Ośrodek Rozwoju Edukacji w ramach projektu „Opracowanie i wdrożenie kompleksowego systemu pracy z uczniem zdolnym” (zob. http://www.ore.edu.pl/).

\section{Rodzina}

Badacze zdolności zwracają także uwagę na znaczenie środowiska rodzinnego we wspieraniu procesu rozwojowego tej grupy. Andrzej Sękowski i Sylwia Gwiazdowska podkreślają w tej kwestii znaczącą rolę rodziny w wielopłaszczyznowym rozwoju uczniów zdolnych, zaznaczając przy tym, że po wejściu dziecka do środowiska szkolnego należy wypracować korzystną formę dialogu pomiędzy rodziną a szkoła, w celu optymalnej współpracy na rzecz wychowanka (Sękowski, Gwiazdowska, 2013, s. 72-82). Józef Chwedorowicz porusza istotny aspekt zarządzania rozwojem zdolności dziecka w środowisku rodzinnym (Chwedorowicz, 2013, s. 17-24), a Marzena Magda-Adamowicz poddaje analizie strukturę rodziny i jej oddziaływania na twórczość dzieci, z której wynika, że potencjały dzieci najlepiej rozwijają się w rodzinach pełnych (Magda-Adamowicz, 2011, s. 193-201). Joanna Łukasiewicz-Wieleba i Alicja Baum wskazują na zależności pomiędzy problemami, które mogą się pojawić w rodzinie, a rozpoznawaniu zdolności dzieci i rozwijania ich potencjału (Lukasiewicz-Wieleba, Baum, 2013, s. 44-58). 


\section{Wnioski}

W zaprezentowanym tekście dokonano próby prezentacji w sposób przeglądowy współczesnych badań z zakresu pedagogiki zdolności (od roku 2000) oraz ujęcia ich w pewne kategorie. Tematyka zdolności wymaga jeszcze wielu rozbudowanych badań, a prowadzone obecnie dezaktualizują się wraz z szybko zmieniająca się rzeczywistością edukacyjną, dlatego inspiruje coraz to nowych badaczy do poszukiwań w zakresie zdolności. Naprzeciw wzmożonym potrzebom tej grupy wychodzą także wciąż niedopracowane i nieadekwatne do przystającej rzeczywistości edukacyjnej rozwiązania systemowe w zakresie wspierania rozwoju uczniów zdolnych. Wiesława Limont krytykuje rozporządzenia i ustawy za ogólny i niejednoznaczny charakter określania zdolności, a także brak konkretnych zapisów w zakresie finansowania inicjatyw (Limont, 2012, s. 29). Badacze polscy starają się sprostać wyzwaniom odkrywania zjawisk edukacyjnych z zakresu zdolności, jednak ich praca stanowi niewielki wycinek w stosunku do wciąż rosnących potrzeb i badań zdolności za granicami kraju. Narasta także potrzeba współpracy i ustalenia wiodącego paradygmatu w zakresie badań nad zdolnościami, co przyczyniłoby się do wzrostu ich znaczenia nie tylko na rynku nauki, ale także w społeczeństwie.

W świecie, w którym kluczowe znaczenia mają kompetencje, nowoczesna osobowość, innowacje, dążenie do samorealizacji i samodoskonalenia, czyli cechy, które charakteryzują osoby zdolne, nie można pozwolić sobie na ich marnotrawienie. Rzetelne badania z zakresu pedagogiki zdolności, nowe rozwiązania systemowe, innowacje w praktyce edukacyjnej, publiczna debata na temat potrzeb osób zdolnych mogą przybliżyć do optymalizacji realizacji celów edukacyjnych uczniów zdolnych.

\section{Bibliografia}

Bandura L. (1974), Uczniowie zdolni i kierowanie ich kształceniem, Nasza Księgarnia, Warszawa.

Bardzińska D. (2013), Nauczyciele uczniów zdolnych - kompetencje, postawy, [w:] M. Jabłonowska (red.), Środowisko edukacyjne uczniów zdolnych, Universitas Rediviva, Warszawa.

Borzym I. (1979), Uczniowie zdolni. Psychologiczne i spoleczne determinanty osiagnięć szkolnych, PWN, Warszawa. 
Chwedorowicz J. (2013), Zarzadzanie rozwojem zdolności dziecka w środowisku rodzinnym, [w:] M. Jabłonowska (red.), Środowisko edukacyjne uczniów zdolnych, Universitas Rediviva, Warszawa.

Chruszczewski M. H. (2009), Profile uzdolnień: intelektualne i osobowościowe składniki uzdolnień plastycznych $i$ muzycznych, Wydawnictwa Uniwersytetu Warszawskiego, Warszawa.

Cieślikowska J., Limont W. (2010), Obraz ucznia zdolnego w potocznych koncepcjach nauczycieli, [w:] W. Limont, J. Cieślikowska, J. Dreszer (red.), Osobowościowe i środowiskowe uwarunkowania rozwoju ucznia zdolnego, WN UMK, Toruń.

Czaja-Chydyba I. (2009), Jak rozwijać zdolności dziecka, WSiP, Warszawa.

Cieślikowska J. (2008), Miejsce nauczyciela $w$ systemie edukacji uczniów zdolnych - na podstawie koncepcji i praktycznych rozwiqzań Josepha Renzulliego, [w:] W. Limont, J. Cieślikowska, J. Dreszer (red.), Zdolności. Talent. Twórczość, t. 1, WN UMK, Toruń.

Cybis N. (2013), Uczeń zdolny - analiza dostępnych narzędzi diagnostycznych: raport przygotowany w ramach projektu Opracowanie i wdrożenie kompleksowego systemu pracy z uczniem zdolnym, Ośrodek Rozwoju Edukacji, Warszawa.

Dąbrowska T., Dyndor L., Foryś M., Gałązka K, Kolczyńska E., Madziara A., Pęczek K., Sprawka E., Wachowicz E. (2013), Model pracy z uczniem zdolnym w gimnazjum, Ośrodek Rozwoju Edukacji, Warszawa.

Didkowska B. (2008), Czy przerysowany rysunek Anime może uczyć kultury wizualnej?, [w:] W. Limont, J. Cieślikowska, J. Dreszer (red.), Zdolności. Talent Twórczość, t. 2, WN UMK, Toruń.

Dyrda B. (2012), Edukacyjne wspieranie rozwoju uczniów zdolnych: studium społeczno-pedagogiczne, Wydawnictwo Akademickie „Żak”, Warszawa.

Dyrda B., Przybylska I. (2008), Emocjonalne i twórcze kompetencje nauczyciela a wspomaganie aktywności twórczej uczniów, [w:] W. Limont, B. Didkowska (red.), Edukacja artystyczna a metafora, WN UMK, Torun.

Dyrda B. (2007), Zjawiska niepowodzeń szkolnych uczniów zdolnych. Rozpoznanie i przeciwdziałanie, Oficyna Wydawnicza „Impuls”, Kraków.

Gabryś K. (2008), O współodpowiedzialności rodziców i pedagogów za rozwój dziecka o specjalnych potrzebach edukacyjnych, [w:] A. Stankowski (red.), Nauczyciel i rodzina w świetle specjalnych potrzeb edukacyjnych dziecka (szkic monograficzny), Wydawnictwo Uniwersytetu Śląskiego, Katowice.

Giza T. (2006), Socjopedagogiczne uwarunkowania procesów identyfikowania oraz rozwoju zdolności uczniów w szkole, Wydawnictwo Akademii Świętokrzyskiej, Kielce. 


\section{METAANALIZY BADAŃ EDUKACYJNYCH}

Jaworski M. (2010), Edukacja artystyczna, uczeń zdolny i przemiany kultury współczesnej, [w:] W. Limont, J. Cieślikowska, J. Dreszer (red.), Osobowościowe i środowiskowe uwarunkowania rozwoju ucznia zdolnego, WN UMK, Toruń.

Kaleńska J. (2008), Efekt Pigmaliona w praktyce. Obraz ucznia zdolnego u nauczycieli szkót muzycznych a oczekiwania wobec jego funkcjonowania na scenie, [w:] W. Limont, J. Cieślikowska, J. Dreszer (red.), Zdolności. Talent. Twórczość, t. 2, WN UMK, Toruń.

Karwowski M. (2005), Konstelacje zdolności: typy inteligencji a kreatywność, Oficyna Wydawnicza „Impuls”, Kraków.

Kossowska M. (2005), Psychologiczne uwarunkowania osiagnięć szkolnych, [w:] A. Sękowski (red.), Psychologia zdolności. Współczesne kierunki badań, WN PWN, Warszawa.

Limont W. (2013), Zdolności jako asynchronia rozwojowa, [w:] M. Jabłonowska (red.), Uczeń zdolny i jego edukacja. Koncepcje. Badania. Praktyka, Universitas Rediviva, Warszawa.

Limont W. (2005), Eksperymentalne badania wyobraźni twórczej, [w:] A. Sękowski (red.), Psychologia zdolności. Współczesne kierunki badań, WN PWN, Warszawa.

Limont W. (2012), Uczeń zdolny. Jak go rozpoznać i jak z nim pracować?, GWP, Sopot.

Łukasiewicz-Wieleba J., Baum A. (2013), Problemy rodzinne a rozpoznawanie zdolności dzieci pochodzacych ze środowiska wiejskiego, [w:] M. Jabłonowska (red.), Środowisko edukacyjne uczniów zdolnych, Universitas Rediviva, Warszawa.

Magda-Adamowicz M. (2011), Struktura rodziny a twórczość dzieci, [w:] J. Łaszczyk, M. Jabłonowska (red.), Wokół problematyki zdolności, Universitas Rediviva, Warszawa.

Mönks F. J. (2005), Zdolności a twórczość, [w:] W. Limont (red.), Teoria i praktyka edukacji uczniów zdolnych, Oficyna Wydawnicza „Impuls”, Kraków.

Przybylska A. (2005), Wykorzystanie metody synektycznej w rozwijaniu wyobraźni, stymulowaniu i ujawnianiu artystycznych zdolności twórczych dzieci w wieku 5-15 lat, [w:] W. Limont (red.), Teoria i praktyka edukacji uczniów zdolnych, Oficyna Wydawnicza „Impuls”, Kraków.

Sękowski A. E. (2005), Inteligencja, twórczość, madrość a wybitne zdolności, [w:] A. Sękowski (red.), Psychologia zdolności. Wspótczesne kierunki badań, WN PWN, Warszawa.

Sękowski A. E. (2001), Osiagnięcia uczniów zdolnych, Lublin.

Sękowski A., Gwiazdowska S. (2013), Rodzina jako środowisko wsparcia ucznia zdolnego, [w:] M. Jabłonowska (red.), Środowisko edukacyjne uczniów zdolnych, Universitas Rediviva, Warszawa. 
Stańczak M. (2009), Zaspokajanie potrzeb ucznia zdolnego w szkole, Wydawnictwo Uniwersytetu Warmińsko-Mazurskiego, Olsztyn.

Uszyńska-Jarmoc J. (2008), Aktywność twórcza jako narzędzie rozwoju i autokreacji człowieka w petnym cyklu życia, [w:] W. Limont, J. Cieślikowska, J. Dreszer (red.), Zdolności. Talent. Twórczość, t. 2, WN UMK, Toruń.

\section{Netografia}

Strategia Lizbońska. Droga do sukcesu zjednoczonej Europy, Departament_Analiz Ekonomicznych i Społecznych, Urząd Komitetu Integracji Europejskiej, https://www.slaskie. pl/STRATEGIA/strat_L.pdf, data dostępu: 2014-01-26.

Informacja o rozprawach doktorskich, https://apd.umk.pl/pl/diplomas/phd/88962/, data dostępu: 2014-05-08.

Ośrodek rozwoju Edukacji: //www.ore.edu.pl, data dostępu: 2014-01-26. 
